\title{
Educação de meninas para uma alimentação "sadia" no \\ Centro de Puericultura do Instituto de Educação de São Paulo (1930)
}

\author{
Girls' education for "healthy" eating at the Childcare Center \\ of the Institute of Education of São Paulo (1930)
}

Ariadne Lopes Ecar ${ }^{1}$

Neste trabalho propomos analisar o papel social e educativo do Centro de Puericultura do Instituto de Educação de São Paulo na década de 1930. O Centro de Puericultura (CP) foi criado em 3 de março de 1933, por iniciativa de alunos da Escola de Professores, sob orientação de Almeida Junior, professor catedrático de Biologia Educacional. As alunas da Escola de Professores eram sócias-contribuintes da instituição e tinham por incumbência angariar sócios fora da escola para assistência às crianças atendidas. Dentro do CP funcionavam as seções de lactário e dispensário. $\mathrm{O}$ Serviço Sanitário mantinha junto ao CP um Dispensário de Puericultura, sob a direção do médico pediatra Sylvio Sucupira, com a colaboração das educadoras sanitárias Mariah Costa Valente e Paula Cecília Dias. Todas as alunas da escola faziam estágio com o médico e as educadoras sanitárias para aprenderem de forma prática sobre a puericultura para, no futuro, ensiná-la nas escolas primárias. As atividades que o CP oferecia podem ser elencadas em: 1) Gabinete médico, com seção de consultas e aulas sobre puericultura pelo pediatra Sylvio Sucupira às estagiárias; 2) Pesagem, com observação da curva de peso e registro em fichários; 3) Costura, com confecção de enxovais pelas alunas da Escola de Professores; 4) Educação, com palestras sobre assuntos de puericultura, feitas pelas estagiárias às mães; 5) Lactário, com preparo dos mingaus especiais, de acordo com as condições de saúde das crianças, dentro das prescrições médicas; e 6) Visitas domiciliares, realizadas pelas alunas aos bairros pobres, com o objetivo de aconselhar sobre a puericultura e a higiene geral. Na área social, o CP prestava assistência à infância, com campanha sistemática e intensa em prol da diminuição da mortalidade infantil, por meio do combate à "miséria" e à "ignorância". No fim da década de 1930 o CP estava sob responsabilidade do Serviço de Saúde Escolar. As fontes utilizadas para a escrita deste trabalho serão os jornais Correio de S. Paulo e Correio Paulistano, as Mensagens do Covernador do Estado de São Paulo (década de 1930), disponíveis na Hemeroteca Digital da Biblioteca Nacional, bem como documentos sobre o Centro de Puericultura do Instituto de Educação acondicionados no Acervo Caetano de Campos, do Centro de Referência em Educação Mário Covas. Utilizaremos o conceito de "retórica" de Michel de Certeau, que significa "um discurso para mudar a vontade do outro". O discurso sobre o que era considerado "sadio" emanado do ensino juntamente com o saber médico gerou a noção do que seria apropriado ou não para a saúde da infância paulista. Desse modo, pretende-se conhecer as atividades do CP e perceber como o ensino foi acionado para intervir na saúde da infância paulista.

Palavras-chave: Centro de Puericultura; alimentação sadia; saúde da infância paulista.

Keywords: Childcare; healthy eating; childhood health in São Paulo.

1 Pós-doutoranda pela Faculdade de Medicina da Universidade de São Paulo (Departamento de Medicina Preventiva). 